\title{
Developing a Model Curriculum for a University Course in Health Impact Assessment in the United States
}

Keshia M. Pollack, PhD, MPH, Department of Health Policy and Management, Johns Hopkins Bloomberg School of Public Health. 624 N. Broadway, Room 557, Baltimore, MD, 21215, kpollac1@,jhu.edu.

Andrew L. Dannenberg, MD, MPH, Department of Environmental and Occupational Health Sciences, University of Washington School of Public Health, 3940 NE Surber Drive, Seattle WA, 98105, adannenberg2@gmail.com.

Nisha D. Botchwey, PhD, MCRP, MPH, School of City and Regional Planning, Georgia Institute of Technology, 245 Fourth Street, NW, Suite 204, Atlanta, GA, 30332, Nisha.Botchwey@,coa.gatech.edu.

Cynthia L. Stone, DrPH, RN, Department of Health Policy and Management, Indiana University School of Public Health, 714 N. Senate Ave EF 204A, Indianapolis, IN 46202, cylstone@iu.edu.

Edmund Seto, $\mathrm{PhD}^{*}$, Department of Environmental and Occupational Health Sciences, University of Washington School of Public Health, 1959 NE Pacific Street, Campus Box 357234, Seattle, WA, 98195, eseto@,uw.edu. *Work completed while on faculty at University of California at Berkeley.

\section{Corresponding Author:}

Keshia M. Pollack, PhD, MPH

Email: kpollac1@jhu.edu

Phone: $410-502-6272$

Fax: 410-614-2797 


\begin{abstract}
As Health Impact Assessment (HIA) become increasingly common in the U.S. there is growing demand for instruction beyond short courses and online training. As of October 2013, there are graduate level courses that include instruction on HIA in at least 17 universities in the U.S., including 4 courses that focus explicitly on HIA. Instructors of these four courses collaborated to develop a model curriculum for teaching HIA that draws on a framework for experiential learning and on a theoretical model of curriculum formulation. This article includes an in-depth analysis of these courses and presents a model curriculum for HIA instruction during an academic quarter or semester course in a University. This model curriculum may help faculty develop a graduate level HIA course at their institution, as well as inform public health and community design professionals interested in building capacity to conduct HIAs, and students considering taking an HIA course. International instructors could also learn from the U.S. experience, and apply the model curriculum to their setting and educational structure.
\end{abstract}

Key Words: HIA, model curriculum, graduate education 


\section{Introduction}

The use of Health Impact Assessment (HIA) in the U.S. has grown rapidly over the last decade. In 2011, the National Research Council published a report presenting a framework for HIA practice in the U.S. (National Research Council 2011). A new professional society SOPHIA (Society of Practitioners of Health Impact Assessment; www.hiasociety.org), was launched in late 2011. As of mid-2014, over 300 HIAs have been completed or are in progress in the U.S. (Health Impact Project 2014). Two national HIA meetings have each attracted approximately 400 attendees. A Medline search for the term "health impact assessment" found the number of articles related to HIA grew from 18 references in 1995-1999 to 271 references in 2010-2014.

As demand to conduct HIAs grows, additional training is needed to build capacity (Dyjack et al. 2013). Most existing HIA trainings range from 1-5 days and are geared to urban planning and public health practitioners. HIA workshops lasting 3-8 hours have been organized at several annual conferences in the U.S.

As a growing field, the introduction of graduate level university courses to train HIA practitioners is of increasing importance. The number of academic institutions offering HIA courses has increased in recent years, creating an opportunity to determine optimal course components to prepare students to conduct HIAs. Although the methods and format to teach HIA vary by institution, identifying a minimum set of core components for HIA courses will strengthen the field by providing a benchmark for instruction. This article offers a HIA model curriculum for use in both schools of urban or city and regional planning (herein referred to as "planning") and schools of public health, based on a review of existing U.S. based courses, theoretical frameworks for educational instruction, and feedback from current courses.

\section{Methods}

Courses were identified by Internet searches and word of mouth among colleagues working in this field. A list of HIA courses compiled by SOPHIA was also reviewed. In addition, Human Impact Partners (www.humanimpact.org) included in its August 2013 electronic newsletter a request for instructors of HIA courses to contact this manuscript's lead author. From these sources, 17 unique courses across the U.S. were identified for potential inclusion. Courses were excluded if they lasted less than an academic quarter (Lehman College; Portland State University); if they had been designed but not yet taught (Georgia Institute of Technology; University of California, Los Angeles); or if instruction on HIA was included as part of a course focused on the built environment or some other topic (Arizona State University, Berea College, Georgia Institute of Technology, Michigan State University, Oregon State University, University of Florida, University of Pennsylvania, University of Virginia, University of Wisconsin).

Courses at four universities - Indiana University (IU), Johns Hopkins University (JHU), University of California at Berkeley (UCB), and University of Washington (UW) - centered on HIA, lasted an academic quarter or semester, and had been taught at least three times as of late 2013 (UCB has been taught since 2006). These criteria facilitated the development of the model curriculum from the most established courses. All syllabi were reviewed to describe key characteristics. Additional information on evaluation measures and course graduates were collected from the course instructors. Authors applied this course synthesis, drawing on dominant theories of learning, and developed a model curriculum for teaching HIA in a university setting. 


\section{Results}

\section{Course Summaries}

Table 1 presents an overview of the 4 courses. The courses were similar in content but varied in length. All courses were taught in graduate schools of public health, with two crosslisted in departments of urban planning (UCB, UW). Class enrollment across the 4 schools ranged from 6 to 27 students, with a median of 14 students. Although not a HIA step, stakeholder engagement is a key aspect of HIA practice, and was addressed in multiple lectures. Instructors used HIA guidance documents including the North American HIA Practice Standards (North American HIA Practice Standards Working Group 2010), and National Research Council HIA report (NRC 2011), as well as training materials from Human Impact Partners (Human Impact Partners Tools and Resources, 2013).

Case examples of completed HIAs were reviewed to help students understand how HIA steps have been applied to various proposals. All courses included an experiential learning component requiring students to work on an HIA or selected steps thereof.

\section{Course Assignments}

Students learned about HIA steps through lectures and readings, and then applied this foundational knowledge as part of their experiential learning. Assignments included an introduction to HIA methods, critical reviews of previously completed HIAs, exercises in the steps of conducting HIAs, and active engagement in conducting an HIA of a current local project often in collaboration with decision-makers. Model HIAs identified by SOPHIA (http://hiasociety.org/?page $\mathrm{id}=57$ ) are particularly useful for in-class examples when detailing the steps of the HIA process. Each course required students to make an oral and/or written critique of a completed HIA, either selected from a list of HIAs or as assigned by the instructor.

Students also worked collaboratively in groups to complete an HIA on a topic of realworld concern identified in partnership with a local stakeholder. In most cases, the instructor identified the topic for the class HIA prior to the beginning of the course. The instructors used their existing networks to identify potential topics, sources of data, and local perspectives on policies. In addition, several instructors are HIA practitioners, and are involved in advisory boards or part of existing HIA groups, which facilitate selection of topics. Table 2 includes a sample of these HIA course topics. Criteria for selecting a class HIA project include having a decision-maker and/or stakeholder willing to interact with the students, being outside of the health sector but with potential health impacts, being local so the students can do a site visit, being finite in scope so the HIA can be completed during the academic term, and being timely so recommendations from the course HIA may be considered in the decision-making process.

The final product included an oral presentation and a written report, which were disseminated on the Internet (UCB, UW, IU) and to the stakeholders directly. The course at UCB asks students to complete the HIA either individually or in teams, with oral and written deliverables and feedback from instructors and student peers along the way, culminating in a final oral presentation to the class. Some of the completed HIAs are submitted to the HIA catalogs on the Human Impact Partners or the Health Impact Project websites (Health Impact Project 2013; Human Impact Partners 2013a).

Although students review the HIA step of monitoring and evaluation, and can complete a process evaluation, it is not feasible for them to evaluate the impact or outcome of their HIA 
during the course. The limited evaluation is included in courses through student reflection on the HIA process, and feedback on the group experience.

\section{Course Evaluations}

End-of-course evaluations suggest that students learned about the HIA process and gained valuable skills in applying HIA to a topic. One frequent comment was that students liked gaining a practical skill, beyond learning theory and foundational knowledge as in many other classes. Students noted skills such as analytics/assessment and systems thinking as being of greatest value. Students in several courses reported positive reactions to stakeholder engagement and interacting with community organizations. Although information on subsequent employment for most students who took these courses is not available, the authors are aware of at least fifteen students who began jobs after graduation where they are part of a team working on a HIA.

\section{Developing a Model Curriculum for HIA}

To develop a model curriculum for HIA, the authors reviewed Tyler's four-step process of curriculum development (stating objectives, selecting learning experiences, organizing learning experiences, and evaluating the curriculum) (2013) and Kolb's experiential learning cycle (abstract conceptualization, active experimentation, concrete experience, and reflective observation) (1984). Together, these approaches support using didactic instruction and experiential learning to teach HIA. Theories of learning also informed the development of a Model Built Environment and Public Health Course, of which two authors of the present paper were involved with creating (Botchwey et al. 2009).

Table 3 presents a Model Curriculum for HIA instruction, derived from the syllabi of the four courses. The authors identified course learning objectives, session topics, potential readings, assignments, and the final course project. A course on HIA should provide students with instruction on the origins of HIA; its key principles (Gothenburg Consensus Paper 1999); the steps and how to apply them in practice; and the potential for, and limitations of, HIA to inform decision-making. The course components described in Table 3 may serve as a framework for HIA instruction and allow flexibility to address institutional context and practical concerns. For example having interdisciplinary teams for the small group projects is only feasible when students in the class come from multiple disciplines, which is more likely if the course is crosslisted in urban planning, public health and other schools in the university. Instructors need to decide whether to focus on a single HIA or on several HIAs for the class project, and how to grade the students for their group contributions and knowledge attained.

\section{Discussion}

The academic community is creating courses to respond to the growth of HIAs in the U.S. This article adds to the extant literature, since prior articles on teaching impact assessments have generally focused on environmental impact assessments (Sanchez \& Morrison-Saunders 2010). A focus on teaching HIA is warranted because of the tremendous growth and demand in the U.S. While this article focused on U.S. courses, instructors from other countries could learn from the U.S. experience and adapt the model curriculum to their institutional setting.

HIA can be taught in many venues, and there are ongoing needs for new and experienced practitioners to acquire the skills necessary to practice HIA effectively. University-based HIA courses serve an important role in preparing future generations of professionals in these fields 
with an appreciation for evaluating health early in planning, working across disciplines, and stakeholder engagement, as well as the skills and practical experience needed to carry out such work (Dyjack et al. 2013; Botchwey \& Trowbridge 2011).

Although short workshops are ideal for professionals (Dyjack et al. 2013), there are some advantages to teaching HIA methods in full-length university courses. First, courses provide depth of HIA skills so that students could be involved and possibly take the lead on conducting HIAs after graduation. As noted, several students who have taken this course are now HIA practitioners. Second, the HIA practicum encourages multidisciplinary collaborations among students in public health, planning and other disciplines. The learning environment also creates interactions with community stakeholders, which provides valuable experiences for students. Third, HIAs conducted in the context of graduate coursework may lead to innovations in HIA practice (e.g., the development of new screening criteria) that have translated to HIAs outside of academia. Finally, each course given may provide a completed HIA, which helps grow the field.

Courses on HIA are attractive for planning students as the curriculum aligns well with the work expected of planners - "to improve the welfare of people and their communities by creating more convenient, equitable, healthful, efficient, and attractive places for present and future generations" (American Planning Association 2013). In schools of planning, an HIA may qualify for internship credit if the HIA is conducted in partnership with an organization external to the academic institution. It also helps planning programs meet Planning Accreditation Board Standards and Criteria (e.g., required planning skills and Values and Ethics) (Planning Accreditation Board 2012).

Courses on HIA can be attractive for public health students since HIA aligns well with several public health core competencies (Calhoun et al. 2008). The accreditation agency for schools of public health requires a minimum number of practicum hours for all MPH students; for one institution (JHU), the HIA course counts for $25 \%$ of the required practicum hours because of the strong experiential learning aspects and partnership with an external agency. Public health faculty seeking to expand practicum experiences for students may consider an HIA course to help address that requirement.

There are challenges to teaching university HIA courses. First, there are time constraints to complete a HIA, especially for a course that occurs over an 8 to 15 week academic quarter or semester. Second, it can be challenging to select the most appropriate and current class HIA project for experiential learning. The screening questions discussed in this article may help to address this challenge. Third, for some institutions, there are limitations on the number of new courses that can be developed annually. In instances when it is not feasible to develop a new course on HIA, faculty should consider including HIA as part of courses on the built environment, environmental health, transportation, or planning, as has occurred in several schools. By focusing on courses that exclusively taught HIA, this study did not review all ways to expose individuals to HIA (e.g., short courses for professionals, pre-conference sessions at meetings). Additional teaching resources including HIA course syllabi are available online (www.bephc.gatech.edu). Finally, evaluation (process, impact, and outcome) and monitoring are key steps of HIA that are discussed but not completed during the courses. HIAs completed as part of courses make important contributions to the field, and it would be useful to monitor the use of class generated HIAs through downloads or local or topical project references, monitor the variables important to the subject HIA, and evaluate their impacts. Impact evaluations could include determining if the HIA was used to help leverage resources or recommendations by 
decision-makers, or resulted in new and/or strengthened cross-sector collaborations. Such evaluations require resources.

\section{Conclusions}

Training in HIA offers the critical analysis of potential impacts of policies, projects, and programs that combines the planning and community design skills of understanding how planning decisions affect communities with the public health skills of surveillance. The core curriculum presented in this paper, which combines didactic and practical instruction, provides a framework for faculty from the U.S. and other countries seeking to develop a HIA course at their own institution and for students who desire to use HIA in their professional careers. 


\section{Acknowledgements}

This work was supported in part by the Johns Hopkins Bloomberg School of Public Health Faculty Innovation Fund. 


\section{References}

American Planning Association. 2013. What is Planning? Available from: http://www.planning.org/aboutplanning/whatisplanning.htm\#2.

Arnstein S. 1969. A Ladder of Citizen Participation. Journal of APA. 35:216-224.

Bhatia R, Wernham A. 2008. Integrating Human Health into Environmental Impact Assessment: An Unrealized Opportunity for Environmental Health and Justice. Environ Health Perspect. 116(8):991-1000.

Bhatia R, Seto E. 2010. Quantitative Estimation in Health Impact Assessment: Opportunities and Challenges. Environmental Impact Assessment Review 31:301-309.

Bhatia R, Coburn J. 2011. Lessons from San Francisco: Health Impact Assessments Have Advanced Political Conditions for Improving Population Health. Health Aff (Millwood). 30:2410-2418.

Birley M. 2011. Health Impact Assessment: Principles and Practice. London: EarthScan/Taylor and Francis.

Bond A, Pope J. 2012. The State of the Art of Impact Assessment in 2012. Impact Assessment and Project Appraisal 20:1-4. Available from: http://dx.doi.org/10.1080/14615517.2012.669140.

Botchwey N, Trowbridge M. 2011. Chapter 23, Training the Next Generation to Promote Healthy Places. In Dannenberg AL, et al, editors, Making Healthy Places: Designing and Building for Health, Well-Being, and Sustainability. Washington DC: Island Press.

Botchwey N, Hobson S, Dannenberg A, Mumford K, Contact C, McMillan T, Jackson R, Lopez R, Winkle C. 2009. A Model Curriculum for a Course on the Built Environment and Public Health: Training for an Interdisciplinary Workforce. Am J Prev Med 36:S63-S71.

Calhou JG, Ramiah K, Weist W, Shortell S. 2008. Development of a Core Competency Model for the Master of Public Health Degree. Am J Public Health 98:1598-1607.

Cole B, Shimkhada R, Fielding J, Kominski G, Morgenstern H. 2005. Methodologies for Realizing the Potential of Health Impact Assessment. Am J Prev Med 28(4):382-89.

Cole B, Fielding J. 2007. Health Impact Assessment: A Tool to Help Policy Makers Understand Health Beyond Health Care. Annu Rev Public Health. 28:393-412.

Dannenberg AL, Wernham A. 2013. Health Impact Assessment: Past Achievement, Current Understanding, and Future Progress. Chapter 23, Health Impact Assessment in the USA. 
Oxford UK: Oxford University Press, 2013.

Dannenberg AL, Bhatia R, Cole B, Dora C, Fielding J, Kraft K, McClymont-Peace D, Mindell J, Onyekere C, Roberts J, Ross C, Rutt C, Scott-Samuel A, Tilson H. 2006. Growing the Field of Health Impact Assessment in the United States: An Agenda for Research and Practice. Am J Public Health 96(2):262-270.

Dyjack D, Botchwey N, Marziale E. 2013. Cross-Sectoral Workforce Development: Examining the Intersection of Public Health and Community Design. J Public Health Manag Pract 19(1):9799.

Gothenburg Consensus Paper. 1999. Health Impact Assessment: Main Concepts and Suggested Approach. Available at: http://www.apho.org.uk/resource/item.aspx?RID=44163.

Gottlieb L, Fielding J, Braveman P. 2012. Health Impact Assessment:

Necessary But Not Sufficient for Healthy Public Policy. Public Health Rep 127:156-62.

Harris-Roxas B. Conceptual Framework for the Impact and Effectiveness of Health Impact Assessment. Centre for Health Equity, Training, Research and Evaluation: Sydney, 2008: Available at: http://hiaconnect.edu.au/old/evaluating hia.htm.

Health Impact Project. 2013. HIA in the United States Interactive Map. Available at: http://www.healthimpactproject.org/hia/us.

Hodge J. 2012. Legal review concerning the use of health impact assessments in nonhealth sectors. Available at: http://www.healthimpactproject.org/resources/body/Legal Review of HIA report.pdf.

Human Impact Partners: HIA Report Guidelines, 2010. Available at: http://www.humanimpact.org/component/jdownloads/finish/11/241.

Human Impact Partners. A Health Impact Assessment Toolkit, $3^{\text {rd }}$ Edition: February, 2011. Available at: http://www.humanimpact.org/component/jdownloads/finish/11/81.

Human Impact Partners. 2013. Tool and Resources. Available at: http://www.humanimpact.org/hips-hia-tools-andresources.

Human Impact Partners. 2013. HIA Toolkit, pages 31-48, Chapters 3,4 (Screening and Scoping) Available at: http://www.humanimpact.org/component/jdownloads/finish/11/81

Kearney M. 2004. Walking the Walk? Community Participation in HIA. A Qualitative Interview Study. Environmental Impact Assessment Review 24:217-29.

Kemm J. 2012. Health Impact Assessment: Past Achievement, Current Understanding, and Future Progress. London: Oxford University Press. 
Kersten E, Rausa J, Schuchter J, Van Erp B. 2011. California's High Speed

Rail: San Jose to Merced Corridor. http://www.healthimpactproject.org/resources/californiahigh-speed-rail-san-jose-to-merced-corridor.

Kolb DA. 1984. Experiential Learning experience as a source of learning and development, New Jersey: Prentice Hall.

Marmot M. 2005. "Social Determinants of Health Inequalities." Lancet 365:1099-104.

Mindell J, Biddulph J, Taylor L, Lock K, Boaz A, Joffe M, Curtis S. 2010. "Improving the Use of Evidence in Health Impact Assessment." Bull World Health Organ 88(7):543-550.

National Research Council (NRC). 2011. Improving Health in the United States: The Role of Health Impact Assessment. Washington, DC: National Academies Press.

North American HIA Practice Standards Working Group. 2010. Minimum Elements and Practice Standards for Health Impact Assessment, Version 2. North American HIA Practice Standards Working Group. Oakland, CA. Available at: http://www.humanimpact.org/doc-lib/finish/11/9.

O'Mullane M. 2013. Integrating Health Impact Assessment into the Policy Process:

Lessons and Experiences from around the World. London: Oxford University Press.

Parry J, Kemm J. 2005. Criteria for Use in the Evaluation of Health Impact

Assessments. Public Health 119(12):1122-1129.

Planning Accreditation Board. Accreditation Standards and Criteria, Approved April 14, 2012.

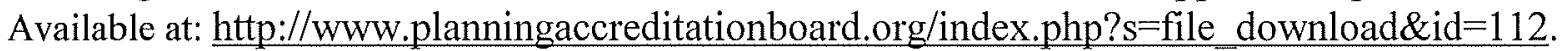

Quigley R, Taylor L. 2004. Evaluating Health Impact Assessment. Public Health 118(8); 544-52.

Ross C, Orenstein M, Botchwey N. 2014. Health Impact Assessment in the United States. Springer. http://www.springer.com/medicine/book/978-1-4614-7302-2?otherVersion=978-14614-7303-9.

Sanchez L, Morrison-Saunders A. 2010. Teaching Impact Assessment: Results of an International Survey. Impact Assessment and Project Appraisal 28(3), 245-250.

Seto E, Holt A, Rivard T, Bhatia R. 2007. Spatial Distribution of

Traffic Induced Noise Exposures in a US City: An Analytic Tool for Assessing the Health Impacts of Urban Planning Decisions. Int J Health Geogr 6:24. doi:10.1186/1476-072X-6-24.

Taylor L, Gowman N, Lethbridge J, Quigley R. 2003. Deciding if a Health Impact Assessment is Required (Screening for HIA) Health Development Agency. Available at: 
http://www.iaia.org/publicdocuments/pubs ref material/Screening\%20for\%20HIA\%20pdf.pdf? AspxAutoDetectCookieSupport=1.\&AspxAutoDetectCookieSupport $=1$.

Tyler R. 2013. Basic Principles of Curriculum and Instruction. First Edition, Revised. Chicago: University of Chicago Press.

Lennert Veerman J, Mackenbach J, Barendregt J. 2007. Validity of Predictions in Health Impact Assessment. J Epidemiol Community Health. 61:362-366.

Wernham A. 2011. Health Impact Assessments are Needed in Decision Making About Environmental and Land-Use Policy. Health Aff(Millwood) 30(5):947-56.

Wismar M, Blau J, Ernst K, Figueras J. The Effectiveness of Health Impact Assessment: Scope and Limitations of Supporting Decision-Making in Europe. Brussels: European Observatory on Health Systems and Policies, 2007. Available at: http://www.euro.who.int/_data/assets/pdf_file/0003/98283/E90794.pdf. 
Table 1. Overview of Four Term Length University HIA Courses in the U.S.

\begin{tabular}{|l|l|l|l|l|}
\hline & $\begin{array}{l}\text { University of California at } \\
\text { Berkeley }\end{array}$ & \multicolumn{1}{|c|}{ Indiana University } & Johns Hopkins University & University of Washington \\
\hline Department & $\begin{array}{l}\text { Department of City and } \\
\text { Regional Planning, and } \\
\text { School of Public Health }\end{array}$ & $\begin{array}{l}\text { Richard M. Fairbanks } \\
\text { School of Public Health, } \\
\text { Department of Health } \\
\text { Policy and Management }\end{array}$ & $\begin{array}{l}\text { Bloomberg School of Public } \\
\text { Health, Department of } \\
\text { Health Policy and } \\
\text { Management }\end{array}$ & $\begin{array}{l}\text { College of Built Environments, } \\
\text { Department of Urban Design } \\
\text { and Planning, and School of } \\
\text { Public Health, Department of } \\
\text { Environmental and } \\
\text { Occupational Health Sciences }\end{array}$ \\
\hline Course Format & $\begin{array}{l}15 \text { weeks; weekly one 3- } \\
\text { hour lecture, discussion, } \\
\text { and group work }\end{array}$ & $\begin{array}{l}15 \text { weeks; one 3-hour } \\
\text { lecture, discussion and } \\
\text { group work }\end{array}$ & $\begin{array}{l}\text { 8 weeks; 2-hour lecture, } \\
\text { discussion, and group work }\end{array}$ & $\begin{array}{l}\text { 10 weeks; weekly: 2 hours per } \\
\text { week, primarily discussions and } \\
\text { group work }\end{array}$ \\
\hline Course Prerequisites & $\begin{array}{l}\text { None } \\
\text { None }\end{array}$ & $\begin{array}{l}\text { Graduate course in health } \\
\text { policy and instructor } \\
\text { permission }\end{array}$ & $\begin{array}{l}\text { None; prior related courses } \\
\text { and/or experiences in health } \\
\text { and built environment, health } \\
\text { policy and urban planning } \\
\text { issues are helpful }\end{array}$ \\
\hline Level of Students & $\begin{array}{l}\text { Graduate students primarily } \\
\text { in planning and public } \\
\text { health }\end{array}$ & $\begin{array}{l}\text { Graduate students primarily } \\
\text { in public health and health } \\
\text { administration program, but } \\
\text { open to others }\end{array}$ & $\begin{array}{l}\text { Graduate students only, } \\
\text { primarily public health and } \\
\text { public policy }\end{array}$ & $\begin{array}{l}\text { Primarily graduate students in } \\
\text { urban planning, public health, } \\
\text { and public policy }\end{array}$ \\
\hline
\end{tabular}


Table 2. Examples of HIA Course Topics in the U.S., 2006-2013

\begin{tabular}{|l|l|}
\hline Institution & HIA Topics \\
\hline $\begin{array}{l}\text { University of California } \\
\text { at Berkeley }\end{array}$ & $\begin{array}{l}\text { Oak to Ninth Redevelopment } \\
\text { California Climate Change Cap and Trade and Carbon Tax }\end{array}$ \\
\hline Indiana University & $\begin{array}{l}\text { Marion County Transportation expansion } \\
\text { Impact of a full service grocery store in the Meadows neighborhood }\end{array}$ \\
\hline $\begin{array}{l}\text { Johns Hopkins } \\
\text { University }\end{array}$ & $\begin{array}{l}\text { Westside-Lexington Market Area Redevelopment } \\
\text { Baltimore City Pool Closing Plan }\end{array}$ \\
\hline $\begin{array}{l}\text { University of } \\
\text { Washington }\end{array}$ & $\begin{array}{l}\text { Duwamish River Superfund Cleanup Project } \\
\text { Tacoma South Downtown Subarea Plan }\end{array}$ \\
\hline
\end{tabular}


Table 3. Proposed Model HIA Course Curriculum

\begin{tabular}{|c|c|c|c|}
\hline \multirow[t]{5}{*}{$\begin{array}{l}\text { Course } \\
\text { Learning } \\
\text { Objectives }\end{array}$} & \multicolumn{3}{|c|}{$\begin{array}{l}\text { - Articulate the value of assessing health impacts of policies and projects to improve population health effects and health } \\
\text { equity. } \\
\text { - Describe the purpose, benefits, and challenges of using HIAs to convey information to decision-makers ways to } \\
\text { mitigate and improve population health effects. } \\
\text { - Describe the core steps used to conduct HIAs including screening, scoping, assessment, recommendations, reporting, } \\
\text { monitoring, and evaluation. } \\
\text { - Summarize the similarities and differences in using HIA as an approach separate from other impact assessments. } \\
\text { - } \text { - Demonstrate collaboration in completing an HIA in an interdisciplinary environment. } \\
\text { - Demonstrate multi-sector and diverse stakeholder engagement. }\end{array}$} \\
\hline & Session Topics & Assignments & $\begin{array}{l}\text { Reference List for } \\
\text { Potential Readings }\end{array}$ \\
\hline & $\begin{array}{l}\text { Introduction/overview of social } \\
\text { determinants of health; overview of HIA } \\
\text { and EIA; state of the field U.S. and and } \\
\text { internationally; institutionalizing HIA } \\
\text { Introduction to HIA Project (scope, } \\
\text { purpose, timeline, etc.) by invited } \\
\text { decision-maker }\end{array}$ & Critique of completed HIA & $\begin{array}{l}\text { Dannenberg and } \\
\text { Wernham 2013; Bond } \\
\text { and Pope 2012; NRC } \\
\text { 2011; Bhatia and } \\
\text { Wernham 2008; } \\
\text { Dannenberg et al. 2006; } \\
\text { Marmot 2005. }\end{array}$ \\
\hline & 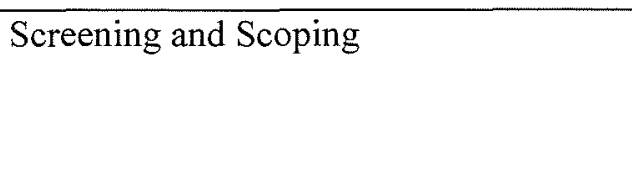 & Complete class project Screening and Scoping & $\begin{array}{l}\text { Human Impact Partners } \\
\text { - HIA Toolkit 2013; } \\
\text { NRC 2011; Taylor et al. } \\
2003 \text {. }\end{array}$ \\
\hline & $\begin{array}{l}\text { Stakeholder Engagement (emphasize its } \\
\text { role throughout the HIA process) }\end{array}$ & Discuss and design project Stakeholder Engagement & $\begin{array}{l}\text { NRC 2011; Kearney } \\
\text { 2004; Arnstein } 1969 .\end{array}$ \\
\hline
\end{tabular}




\begin{tabular}{|c|c|c|c|}
\hline & $\begin{array}{l}\text { Assessment: baseline and impact } \\
\text { assessment; quantitative and qualitative } \\
\text { methods; data sources }\end{array}$ & Draft Assessment of class project & $\begin{array}{l}\text { NRC 2011; Human } \\
\text { Impact Partners } 2011 \text {; } \\
\text { Bhatia and Seto 2010; } \\
\text { Seto et al. 2007; Cole et } \\
\text { al. } 2005 .\end{array}$ \\
\hline & Recommendations & Draft project Recommendations & $\begin{array}{l}\text { NRC 2011; Human } \\
\text { Impact Partners } 2010 .\end{array}$ \\
\hline & Reporting & $\begin{array}{l}\text { Develop plan for Reporting (and communicating and } \\
\text { dissemination) findings }\end{array}$ & $\begin{array}{l}\text { NRC 2011; Human } \\
\text { Impact Partners } 2010 .\end{array}$ \\
\hline & $\begin{array}{l}\text { Evaluation } \\
\text { Monitoring }\end{array}$ & $\begin{array}{l}\text { Draft Process Evaluation of class project and discuss } \\
\text { approach for Impact and Outcome Evaluation } \\
\text { Draft project Monitoring Plan }\end{array}$ & $\begin{array}{l}\text { NRC 2011; Bhatia and } \\
\text { Coburn 2011; Mindell } \\
\text { et al. 2010; Harris- } \\
\text { Roxas 2008; Wismar et } \\
\text { al., 2007; Parry and } \\
\text { Kemm 2005; Quigley } \\
\text { and Taylor 2004. }\end{array}$ \\
\hline & Using policy tools to facilitate HIA & Allow in-class time to work on HIA & $\begin{array}{l}\text { Gottlieb et al., 2012; } \\
\text { Hodge 2012; Wernham } \\
\text { 2011; Cole and Fielding } \\
2007 .\end{array}$ \\
\hline & $\begin{array}{l}\text { Presentation of class project to decision- } \\
\text { maker }\end{array}$ & $\begin{array}{l}\text { Oral presentation by students to decision-maker } \\
\text { summarizing the HIA and its recommendations, and } \\
\text { decision-maker is invited to respond }\end{array}$ & \\
\hline Assignments & $\begin{array}{l}\text { Review of a Completed HUA } \\
\text { Write 4-5 page paper review of a } \\
\text { completed HIA including a } \\
\text { summary of the proposed project } \\
\text { or policy; methods; major } \\
\text { findings; recommendations; }\end{array}$ & $\begin{array}{l}\text { Students can select completed HIAs from: } \\
\text { http://www.healthimpactproject.org/hia/us; or } \\
\underline{\text { http://hiasociety.org/?page id }=57}\end{array}$ & \\
\hline
\end{tabular}




\begin{tabular}{|l|l|l|}
\hline & $\begin{array}{l}\text { reporting; strengths and } \\
\text { limitations, and impact measures, } \\
\text { if available. }\end{array}$ \\
\hline $\begin{array}{l}\text { Class HIA } \\
\text { Project }\end{array}$ & \begin{tabular}{l} 
Complete a HIA to identify the potential health impacts of a current proposed local project or policy. \\
(1) Conduct screening and scoping \\
(2) Design Stakeholder engagement \\
(3) Conduct assessment \\
(4) Draft recommendations \\
(5) Draft monitoring plan \\
(6) Draft process evaluation, and discuss approach for impact and outcome evaluations \\
(7) Present results and recommendations to decision-maker \\
(8) Write individual reflections on impressions of the field of HIA and the class project, including comments on what was \\
\hline Select \\
Suggested \\
Textbooks
\end{tabular} \\
$\begin{array}{l}\text { - Ross C, Orenstein M, Botchwey N. 2014. Health Impact Assessments in the USA. } \\
\text { - Oround the World. }\end{array}$ \\
\hline
\end{tabular}

